\title{
REVISTA DE DIREITO DA
}

\section{ADMINISTRAÇÃO PUBLICA}




\section{REVISTA DE DIREITO DA \\ ADMINISTRAÇÃo PÚBLICA}

ANO No 02 - VolUME No 01 - EDIÇÃo No 03 - JUL/DeZ 2017

ISSN 2595-5667

Rio de Janeiro

2017 


\title{
Revista de Direito da Administração Pública Law Journal of Public Administration
}

\author{
Conselho Editorial: \\ Sr. Alexander Espinosa Rausseo, Universidad Central de Venezuela. \\ Sra. Maria de Los Angeles Fernandez Scagliusi, Universidad de Sevilla. \\ Sr. Luis Guillermo Palacios Sanabria, Universidad Austral de Chile. \\ Sr. Mustafa Avci, University of Anadolu Faculty of Law. \\ Sr. Adilson Abreu Dallari, Pontifícia Universidade Católica de São Paulo. \\ Sr. Alexandre Veronese, Universidade de Brasília. \\ Sr. Carlos Ari Sundfeld, Fundação Getúlio Vargas de São Paulo. \\ Sra. Cristiana Fortini, Universidade Federal de Minas Gerais. \\ Sr. Daniel Wunder Hachem, Universidade Federal do Paraná. \\ Sra. Maria Sylvia Zanella di Pietro, Universidade de São Paulo. \\ Sr. Paulo Ricardo Schier, Complexo de Ensino Superior do Brasil. \\ Sr. Vladimir França, Universidade Federal do Rio Grande do Norte. \\ Sr. Thiago Marrara, Universidade de São Paulo. \\ Sr. Wilson Levy Braga da Silva Neto, Universidade Nove de Julho

\section{Avaliadores desta Edição:} \\ Profa. Andréia Gomes, UFF. \\ Prof. Bruno Teixeira Marcelos, UFF. \\ Profa. Debora Sotto, PUC-SP. \\ Prof. Dr. Emerson Moura, UFRRJ. \\ Prof. Dr. Henrique Cardoso, UFS. \\ Profa. Dra. Irene Nohara, Mackenzie. \\ Prof. João Pedro Accioly, UERJ. \\ Prof. Ms. Paulo Macera, USP. \\ Prof. Silvio Teixeira da Costa, PUC-MG. \\ Prof. Dr. Victor Aguiar Jardim, IDP.
}

Prof. Adriano de Souza Martins, UERJ.

Profa. Ariane Shermam Morais, UFMG.

\section{Diagramação e Layout:}

Prof. Dr. Emerson Affonso da Costa Moura, UFRRJ. 


\section{SUMÁRIO}

Apresentação 005

Emerson Affonso da Costa Moura

A Penalização da Pessoa Jurídica na Lei Anticorrupção: Uma Análise do Art. 30 da Lei no 12.846/13 à luz do Princípio do "Non Bis In Idem" 006

Gabriel Farjado

Parcerias da Administração Pública com as Organizações Sociais na Prestação do Serviço Público de Saúde 037

Rossana Cláudia dos Santos Braga

A Teoria da Desconsideração da Personalidade Jurídica na Lei 12.846/2013 075

Augusto de Paiva Siqueira

A Aplicação da Arbitragem na Resolução de Conflitos da Administração Pública 110 Natália Alves da Silva

Sistema Notarial Brasileiro versus Norte Americano: Comparação pelas diferenças 148 Maria-Maria Martins Silva Stancati

Intervenção do Estado na Propriedade em Prol da Preservação do Patrimônio Cultural: Uma Análise do Tombamento da Igreja de Nosso Senhor dos Passos e a Limitação ao Direito de Construir

Tauã Lima Verdan Rangel 


\section{A TEORIA DA DESCONSIDERAÇÃO DA PERSONALIDADE JURÍDICA NA LEI $12.846 / 2013$}

\section{THE THEORY OF DEDUCTION OF LEGAL PERSONALITY IN LAW 12,846 / 2013}

Data de submissão: 23/08/2017

Data de aprovação: 22/12/2017

\section{AUGUSTO DE PAIVA SIQUEIRA}

Graduando em Direito pela Pontifícia Universidade Católica de Goiás. Membro do Núcleo de Estudos e Pesquisa em Direito Econômico e Comercial da Faculdade de Direito da UFG.

RESUMO: O presente trabalho propõe-se a analisar a Lei no 12.846/2013, conhecida como "Lei Anticorrupção das Pessoas Jurídicas”, que dispõe sobre a responsabilização administrativa e civil de pessoas jurídicas pela prática de atos contra a administração pública, nacional ou estrangeira. O foco do trabalho é a aplicação da teoria da desconsideração da personalidade jurídica no curso do processo administrativo de responsabilização, previsto no artigo 14 da Lei. As pessoas físicas dos sócios administradores, ou com poderes de administração, poderão se responsabilizar pelas sanções previstas na Lei Anticorrupção por meio da técnica da desconsideração da personalidade jurídica, sem o aval do Poder Judiciário. Ao final, será considerado o posicionamento dos tribunais superiores e da doutrina nacional sobre a temática.

PALAVRAS-CHAVES: Desconsideração da personalidade jurídica; Processo administrativo; de responsabilização; Lei Anticorrupção; Compliance; Responsabilidade Objetiva.

ABSTRACT: This work analyses the Law number 12.846/2013, commonly known as the "Legal Entity Anticorruption Law", regarding the administrative and civil accountability of legal entities that practiced acts against a public, a national or a foreign administration. It focuses on the application of the lifting the corporate veil theory during the administrative process of accountability, set forth in article 14 of said Law. Through said theory's techniques, the Anti-corruption law sanctions shareholders, acting as board members or with administrative powers, without approval from the Judiciary. This work, also covers the standing of Superior Courts and the domestic doctrine about the theme.

KEYWORDS: Lifting the Corporate Veil. Administrative Process of Accountability. Anti-corruption Law. Compliance. Objective liability. 


\section{INTRODUÇÃO}

A Lei 12.846/2013, também conhecida como "Lei Anticorrupção das Pessoas Jurídicas", incorporou-se ao ordenamento jurídico brasileiro com a finalidade de suprir a lacuna legislativa até então vigente no tocante ao combate à corrupção.

O advento da Lei se deu em razão dos compromissos internacionais assumidos pelo Brasil, bem como da pressão pela comunidade internacional de que fosse promovida uma adequação do ordenamento jurídico brasileiro à estratégia global de combate à corrupção.

Com a finalidade de positivar mecanismos efetivos de responsabilização, a Lei Anticorrupção dispôs, como seu principal instrumento, a responsabilidade objetiva, civil e administrativa das pessoas jurídicas. Além da objetiva responsabilização, a Lei conta com artigos que preveem a imposição de multas na esfera administrativa, a possibilidade de infratores firmarem acordos de leniência e os regimes de integridade e compliance.

Dentre os mais variados aspectos da Lei $n^{\circ} 12.846 / 2013$, optou-se pelo estudo do artigo 14, que prevê a possibilidade de aplicação da desconsideração da personalidade jurídica no curso do processo administrativo de responsabilização e a consequente extensão das sanções previstas no diploma legal aos sócios-administradores e com poderes de administração.

O presente trabalho divide-se em três seções. O primeiro deles é aplicado ao estudo da origem da Lei $n^{\circ}$ 12.846/2013 e a sua inserção no ordenamento jurídico brasileiro. Serão abordados os contextos nacional e internacional que foram relevantes para o seu advento e, ao final, será analisado, de maneira breve, o escopo fundamental da Lei Anticorrupção, com os principais mecanismos nela previstos.

Na segunda seção, será realizada uma imersão na teoria da desconsideração da personalidade jurídica. Assim, passar-se-á a um estudo acerca do seu conceito, características e pressupostos e as correntes doutrinárias que a sustentam, bem como sua previsão no direito brasileiro.

Por fim, na terceira seção, será discutida, de fato, a questionada previsão contida no artigo 14 da Lei em estudo, que dispõe sobre a possibilidade da Administração Pública desconsiderar a personalidade jurídica das sociedades, no curso dos processos administrativos de responsabilização, a fim de estender os efeitos das sanções previstas na lei de regência aos sócios-administradores e com poderes de administração. 
As críticas ao disposto no artigo 14 são embasadas, sobretudo, na ausência de autorização constitucional para a suspensão da autonomia patrimonial das sociedades sem um pronunciamento jurisdicional.

Diante desse cenário, serão analisados os posicionamentos doutrinários divergentes acerca da problemática em questão, com a ponderação de princípios constitucionais, em cotejo com as orientações jurisprudenciais já dadas pelas instâncias superiores acerca da viabilidade ou não da aplicação da disregard doctrine no curso dos processos administrativos.

\section{DESENVOLVIMENTO}

\section{SEÇÃO I - DA LEI ANTICORRUPÇÃO DAS PESSOAS JURÍDICAS}

\section{I.I. BREVE HISTÓRICO DA LEI No 12.846/13}

\section{I.I.I. Contexto Internacional}

O advento da Lei $n^{\circ} 12.846 / 2013$, também denominada Lei Anticorrupção das Pessoas Jurídicas, está intimamente ligado à história das discussões travadas no âmbito internacional no tocante ao combate à corrupção envolvendo as empresas e o Poder Público. Sobre essas discussões, torna-se necessário fazer breves considerações acerca de relevantes passagens históricas na trajetória do combate à corrupção e que culminaram no advento da Lei em estudo.

Pode-se dizer que o ponto de partida dessa trajetória iniciou-se na década de 1970, nos Estados Unidos da América (EUA), com a edição da normativa anticorrupção norteamericana Foreign Corrupt Practices Act (FCPA) em 1977. Para o advento da referida norma, o contexto político pelo qual passava o país foi decisivo, visto que as investigações empreendidas no período pós-escândalo de Watergate denunciaram a ineficácia do conjunto legislativo estadunidense no tocante à punição das práticas de suborno de funcionários públicos estrangeiros pelas empresas (VAZ; MOROSINI, 2013, p. 263).

A lei anticorrupção norte-americana foi editada, sobretudo, com a finalidade de coibir as práticas de suborno de funcionários públicos e criou diversas obrigações para empresas americanas quanto ao registro de suas transações no exterior. Para coibir as práticas de suborno, a normativa estadunidense passou a prever, entre outras medidas, a 
responsabilização criminal e civil de pessoas físicas e jurídicas, bem como a previsão de multas vultosas aos infratores.

Contudo, em que pese o grande passo dado com a edição da FCPA, foi somente na década de 1990 que os casos de corrupção internacional tornaram-se mais graves e tomaram o centro das atenções, como também se tornaram a pauta das discussões na comunidade internacional.

O primeiro instrumento internacional de combate à corrupção se deu em 1996, com a criação da "Convenção Interamericana contra a Corrupção" (CICC) pelos países membros da Organização dos Estados Americanos (OEA). O referido acordo foi extremamente influenciado pela normativa anticorrupção norte-americana e estabeleceu medidas preventivas e repressivas a serem adotadas pelos Estados-Membros, como, por exemplo: a proibição da oferta de subornos a funcionários públicos nacionais e estrangeiros; a proteção dos denunciantes; a criação de uma agenda governamental para controle de corrupção e a obrigação de manter registros contábeis das empresas com o fim de facilitar a detecção da corrupção (GRECO FILHO; RASSI, 2015, p. 34).

Apesar dos avanços alcançados até então, o combate à corrupção ainda carecia de um alcance global, visto que a CICC se adstringia aos países membros da OEA e não era vinculada a grande parte da comunidade internacional.

Também havia uma forte pressão, por parte dos EUA, para que fosse criada uma convenção internacional que instituísse um regime internacional amplo de combate à corrupção, visto que as pesadas sanções previstas pela FCPA só afetavam as empresas norteamericanas, enquanto que suas concorrentes, situadas em outros países, principalmente europeus, estavam livres das amarras impostas pela norma e se beneficiavam com a ausência de um regime internacional capaz de lhes atribuir a responsabilização pelas práticas de suborno de agentes públicos.

Nesse diapasão, visando ampliar a projeção do combate à corrupção, em dezembro de 1997 foi assinada a "Convenção sobre o Combate da Corrupção de Funcionários Públicos Estrangeiros em Transações Comerciais Internacionais", também conhecida como “Convenção Antissuborno", da Organização para Cooperação e Desenvolvimento Econômico (OCDE), que tratou, especificamente, da corrupção envolvendo funcionários públicos estrangeiros.

Entre as medidas previstas na "Convenção Antissuborno" da OCDE, destacam-se: a adoção de um conceito amplo de "funcionário público estrangeiro", a imposição de sanções 
de natureza civil e administrativa, bem como a responsabilidade da pessoa jurídica pela corrupção de funcionário público estrangeiro de acordo com os princípios do Estado signatário ${ }^{168}$.

Com o advento da Convenção, a OCDE começou a emitir recomendações a fim de detalhar as obrigações constantes no documento internacional. Tais recomendações sugeriam que os membros signatários adotassem, entre outras medidas, a criação de "programas de controle interno, ética e conformidade" e uma cultura de transparência nos negócios, a fim de prevenir e detectar casos de corrupção transnacional.

Após a iniciativa da OCDE, vários tratados regionais internacionais anticorrupção foram firmados ao redor do mundo. Diante dessa busca internacional pela criação de aparatos legais aptos a combater as práticas corruptivas, a Organização das Nações Unidas (ONU) criou, em 2003, a "Convenção das Nações Unidas contra a Corrupção", que passou a ser o primeiro instrumento legal vinculante sobre a temática no âmbito global (MACHADO, 2010, apud, GRECO FILHO; RASSI, 2015, p. 41).

Em linhas gerais, Vicente Greco Filho e João Daniel Rassi (2015, p. 41), afirmam que a Convenção da ONU contra a Corrupção foi dirigida à prevenção e repressão da corrupção no tocante ao desvio funcional de agentes públicos nacionais e estrangeiros. Do mesmo modo, preconizou a adoção de medidas de comportamento ético para empresas, a transparência na Administração, o combate à lavagem de valores, a incriminação do enriquecimento ilícito, a adoção de medidas contra a obstrução da Justiça e a possível incriminação do chamado "suborno" de agentes não públicos.

Diante dessa movimentação internacional contra o fenômeno da corrupção, o Brasil ratificou as Convenções supracitadas, incorporando-as ao ordenamento jurídico nacional nos moldes dos seguintes decretos: Decreto $n^{\circ}$ 4.410/2002 (Convenção Interamericana contra a Corrupção, de 1996); Decreto no 3.678/2000 (Convenção sobre o Combate à Corrupção de Funcionários Públicos Estrangeiros em Transações Comerciais Internacionais, de 1997) e Decreto $n^{0}$ 5.687/2006 (Convenção das Nações Unidas contra a Corrupção, de 2002).

No entanto, mesmo o Brasil tendo se tornado signatário dessas convenções, até o ano de 2013 o ordenamento jurídico brasileiro apresentava lacunas que demonstravam não satisfazer plenamente os compromissos internacionais firmados, como, por exemplo, a não previsão expressa de responsabilização das pessoas jurídicas por atos ilícitos praticados contra a Administração Pública.

${ }^{168} \mathrm{O}$ texto da convenção está disponível em <http://www.oecd.org/daf/antibribery/ConvCombatBribery ENG.pdf>. Acesso em 26 de novembro de 2016. 


\subsubsection{Contexto Nacional}

Até o ano de 2013, o papel de enfrentamento à corrupção no Brasil era conferido aos crimes de corrupção e similares, previstos no Código Penal, aos delitos previstos na Lei $\mathrm{n}^{\circ}$ 8.666/93 (Lei de Licitações e Contratações Públicas), na Lei nº 8.429/92 (Lei de Improbidade Administrativa) e a outras leis esparsas. No entanto, para Igor Sant'Anna Tamasuskas e Pierpaolo Cruz Bottini (2014, p. 134), pela ótica do legislador, o aparato legislativo vigente à época não era suficiente para o combate eficaz à corrupção. Os tipos penais, nessa seara, se limitavam a responsabilizar pessoas físicas, sem afetar aquela que, em regra, é a maior beneficiária da corrupção: a empresa.

Diante da ineficácia do conjunto legislativo, em fevereiro de 2010, a Presidência da República submeteu ao Congresso Nacional o Projeto de Lei $n^{\circ} 6.826$, cuja redação original havia sido de responsabilidade da Controladoria-Geral da União, do Ministério da Justiça e da Advocacia-Geral da União. A finalidade do projeto submetido à Casa Legislativa era, conforme o descrito na mensagem presidencial: "suprimir uma lacuna existente no sistema jurídico pátrio no que tange à responsabilização de pessoas jurídicas pela prática de atos ilícitos contra a Administração Pública, em especial, por atos de corrupção em licitações e contratos administrativos"169. Significa dizer que não havia, até então, dispositivos legais constantes no sistema brasileiro capazes de atribuir a responsabilização às pessoas jurídicas, que, praticamente, saiam impunes quando envolvidas em ilícitos praticados contra o Poder Público.

Todavia, muito se discutiu a respeito de uma normativa anticorrupção direcionada à responsabilização das empresas. A principal resistência ao PL n ${ }^{\circ} 6.826 / 2010$, no Congresso Nacional, foi a previsão da responsabilidade objetiva das pessoas jurídicas, no âmbito civil e administrativo, quando envolvidas em atos ilícitos praticados contra a Administração Pública. Isto é, conforme previa o Projeto de Lei, para a responsabilização das pessoas jurídicas bastava tão somente a comprovação do ato ilícito praticado, o nexo de causalidade e o dano suportado pela Administração Pública ou o benefício recebido pela empresa infratora pela prática da ilicitude, prescindindo, outrossim, da averiguação de culpa ou dolo.

Evidente é que a referida previsão gerou muita discussão e polêmica no meio político e empresarial, ao prever a possibilidade de que grandes empresas pudessem ser

169 Tanto o PL $\mathrm{n}^{\mathrm{o}} \quad 6.826 / 2010$ quanto a Mensagem $\mathrm{n}^{\mathrm{o}}$ 52/2010 estão disponíveis em: <http: //www.camara.gov.br/proposicoesWeb/fichadetramitacao?idProposicao=466400>. Acesso em 13 de novembro de 2016.

Revista de Direito da Administração Pública, ISSN 2595-5667, a. 2, v. 1, n. 3, julho-dezembro, 2017, p. 80 
responsabilizadas pela prática de atos ilícitos realizados pelos seus funcionários e prepostos em detrimento dos interesses do Poder Público. Não à toa, o Congresso Nacional tentou vetar a modalidade objetiva de responsabilização ao sugerir que deveria constar da redação do artigo $19, \S 2^{\circ}$ a necessidade de comprovação de culpa ou dolo para a aplicação das sanções constantes na lei, aproximando a norma à mesma lógica de responsabilização subjetiva prevista na Lei de Improbidade Administrativa (Lei $n^{\circ}$ 8.429/92) e na Lei de Licitações e Contratos Administrativos (Lei no 8.666/93) ${ }^{170}$ (MOREIRA; BAGATIN, 2014, p. 59).

Em contrapartida ao texto sugerido pela Casa Legislativa, o veto presidencial afastou a ideia da responsabilidade subjetiva e manteve a lógica inicial da objetivação da responsabilidade, assegurando o que mais tarde representaria um dos pilares fundamentais da Lei Anticorrupção. O mencionado veto destacou:

Tal como previsto, o dispositivo contraria a lógica norteadora do projeto de lei centrado na responsabilidade objetiva de pessoas jurídicas que cometam atos contra a administração pública. A introdução da responsabilidade subjetiva anularia todos os avanços apresentados pela nova lei, uma vez que não há que se falar na mensuração da culpabilidade de uma pessoa jurídica. ${ }^{171}$

Desta feita, com a manutenção da previsão da responsabilidade objetiva, a Lei Anticorrupção representou um marco no tocante ao enfrentamento à corrupção, na medida em que dispôs sobre a responsabilização objetiva nas esferas administrativa e civil e adotou uma noção ampla da pessoa jurídica, bem como objetivou dar cumprimento aos tratados internacionais, dos quais o Brasil é signatário.

\section{I.2 ESCOPO FUNDAMENTAL DA LEI Nº 12.846/13}

O advento da Lei $\mathrm{n}^{\mathrm{o}}$ 12.846/13, de $1^{\circ}$ de agosto de 2013, objetivou dar cumprimento aos compromissos internacionais firmados pelo Brasil, notadamente as diretrizes da Convenção das Nações Unidas contra a Corrupção, instituindo a possibilidade de

\footnotetext{
170 A redação sugerida pelo Congresso Nacional era a seguinte: "art. 19, §2: "Dependerá da comprovação de culpa ou dolo a aplicação das sanções previstas nos incisos II a IV deste artigo". Os incisos II a IV de que tratam a redação sugerida pelo Congresso dispunham sobre: "II - suspensão ou interdição parcial de suas atividades; III - dissolução compulsória da pessoa jurídica; IV - proibição de receber incentivos, subsídios, subvenções, doações ou empréstimos de órgãos ou entidades públicas e de instituições financeiras públicas ou controladas pelo poder público, pelo prazo mínimo de 1 (um) e máximo de 5 (cinco) anos".

${ }^{171}$ Disponível em: <http: //www.planalto.gov.br/ccivil_03/_ato2011-2014/2013/Msg/VEP-314.htm>. Acesso em 13 de novembro de 2016 
responsabilização das empresas que causassem prejuízos à Administração mediante atos de corrupção ou análogos.

Vicente Greco Filho e João Daniel Rassi (2015, p.16) atribuem ao termo "corrupção" um sentido amplo, definindo-o como:

[...] qualquer locupletamento indevido decorrente da prática de ato ilegal ou mesmo antiético para beneficiar alguém ou facilitar alguma atividade, ainda que legítima de outrem, ou, ainda comportar-se de maneira indevida para obter algum benefício para si ou para outrem, ainda que sem conteúdo econômico (GRECO FILHO; RASSI, 2015, p. 16).

Parece que essa noção ampla de corrupção foi o sentido que a lei pretendeu atribuir ao termo, ou seja, o mais abrangente possível.

Considerando a natureza da responsabilidade da pessoa jurídica escolhida pela Lei $\mathrm{n}^{\mathrm{o}} 12.846 / 13$, é possível notar que o legislador buscou contornar as dificuldades que enfrentaria o diploma legal caso fosse adotada a responsabilidade penal das pessoas jurídicas (SARCEDO, 2016, p. 132). É sabido que a Constituição Federal de 1988 apenas previu a possibilidade de responsabilização penal das companhias em caso de crimes praticados contra o meio ambiente (art. $\left.225, \S 3^{\circ}\right)^{172}$ e contra a ordem financeira, bem como em desfavor da economia popular (art. 173, $\left.\S 5^{\circ}\right)^{173}$, permanecendo, no entanto, silente no que toca aos crimes praticados contra a Administração Pública.

Contornando essa lacuna legislativa, a Lei em estudo acabou adotando um modelo de direito administrativo sancionador, cominando sanções civis e administrativas às pessoas jurídicas, a fim de evitar discussões a respeito da constitucionalidade da norma ou mesmo da incompatibilidade do instituto da responsabilidade penal com a natureza jurídica dos entes coletivos.

No entanto, em que pese a expressa adoção da responsabilidade civil e administrativa, parte da doutrina tem defendido que a Lei em questão é verdadeiramente uma

172 Art. 225. Todos têm direito ao meio ambiente ecologicamente equilibrado, bem de uso comum do povo e essencial à sadia qualidade de vida, impondo-se ao Poder Público e à coletividade o dever de defendê-lo e preservá- lo para as presentes e futuras gerações.

(...)

$\S 3^{\circ}$ As condutas e atividades consideradas lesivas ao meio ambiente sujeitarão os infratores, pessoas físicas ou jurídicas, a sanções penais e administrativas, independentemente da obrigação de reparar os danos causados.

173 Art. 173. Ressalvados os casos previstos nesta Constituição, a exploração direta de atividade econômica pelo Estado só será permitida quando necessária aos imperativos da segurança nacional ou a relevante interesse coletivo, conforme definidos em lei.

(...)

$\S 5^{\circ}$ A lei, sem prejuízo da responsabilidade individual dos dirigentes da pessoa jurídica, estabelecerá a responsabilidade desta, sujeitando-a às punições compatíveis com sua natureza, nos atos praticados contra a ordem econômica e financeira e contra a economia popular. 
norma penal encoberta. Eduardo Saad Diniz e Renato Mello Jorge Silveira (2015, p. 308) ressaltam que, apesar da Lei não ser formalmente penal, esta representa um conteúdo nitidamente criminal, visto que seus efeitos e formas sancionatórias têm forte incidência na restrição de direitos e repercutem seriamente na aplicação de condenações criminais.

Ainda que afastada a natureza penal da Lei, é evidente que a adoção da responsabilidade objetiva, nas esferas civil e administrativa, representou um verdadeiro marco no contexto do combate à corrupção, ao colocar os entes coletivos diante do risco de se verem responsabilizados pela prática de atos executados por seus prepostos.

Nesse sentido, destaca-se a noção ampla atribuída pelo legislador ao identificar o sujeito ativo dos delitos previstos na Lei. O parágrafo único do artigo $1^{\mathbf{0} 174}$ elenca as pessoas jurídicas que serão consideradas como sujeito ativo dos atos de corrupção, sendo elas: as pessoas jurídicas de fato e de direito, organizadas empresarialmente ou não, tendo ou não fins lucrativos, podendo ser personificadas ou não.

Nessa linha, acrescenta Modesto Carvalhosa (2015, p. 62-63) que quando a Lei fala de sociedades empresariais, não está identificando aquelas com fins lucrativos que organizam os fatores de produção, no conceito clássico de empresa, mas a forma de organização e de governança da pessoa jurídica, independentemente de ter fins lucrativos ou associativos, beneméritos ou assistenciais.

Desta feita, o que se percebe é que a Lei Anticorrupção, ao positivar a responsabilidade objetiva nos âmbitos civil e administrativo para a imposição das sanções e adotar a concepção ampla de pessoa jurídica como sujeito ativo dos delitos do art. $5^{\circ 175}$,

\footnotetext{
${ }^{174}$ Art. 10 Esta Lei dispõe sobre a responsabilização objetiva administrativa e civil de pessoas jurídicas pela prática de atos contra a administração pública, nacional ou estrangeira.

Parágrafo único. Aplica-se o disposto nesta Lei às sociedades empresárias e às sociedades simples, personificadas ou não, independentemente da forma de organização ou modelo societário adotado, bem como a quaisquer fundações, associações de entidades ou pessoas, ou sociedades estrangeiras, que tenham sede, filial ou representação no território brasileiro, constituídas de fato ou de direito, ainda que temporariamente.

${ }^{175}$ Art. 5o Constituem atos lesivos à administração pública, nacional ou estrangeira, para os fins desta Lei, todos aqueles praticados pelas pessoas jurídicas mencionadas no parágrafo único do art. 1ํㅜ , que atentem contra o patrimônio público nacional ou estrangeiro, contra princípios da administração pública ou contra os compromissos internacionais assumidos pelo Brasil, assim definidos:

I - prometer, oferecer ou dar, direta ou indiretamente, vantagem indevida a agente público, ou a terceira pessoa a ele relacionada;

II - comprovadamente, financiar, custear, patrocinar ou de qualquer modo subvencionar a prática dos atos ilícitos previstos nesta Lei;

III - comprovadamente, utilizar-se de interposta pessoa física ou jurídica para ocultar ou dissimular seus reais interesses ou a identidade dos beneficiários dos atos praticados;

IV - no tocante a licitações e contratos:

a) frustrar ou fraudar, mediante ajuste, combinação ou qualquer outro expediente, o caráter competitivo de procedimento licitatório público;

b) impedir, perturbar ou fraudar a realização de qualquer ato de procedimento licitatório público;

c) afastar ou procurar afastar licitante, por meio de fraude ou oferecimento de vantagem de qualquer tipo;

Revista de Direito da Administração Pública, ISSN 2595-5667, a. 2, v. 1, n. 3, julho-dezembro, 2017, p. 83
} 
objetivou o fortalecimento do ambiente institucional de repressão à corrupção, estimulando o compromisso empresarial com a cultura ética e incentivando as empresas a adotarem mecanismos internos de prevenção de atos ilícitos, como políticas de integridade e compliance, que evitem qualquer ligação da companhia com pessoas ou outras entidades que possam, de alguma forma, trazer-lhe prejuízos.

Ao estimular que as empresas adotem os mecanismos de integridade $\mathrm{e}$ compliance, a Lei em estudo reforçou seu caráter eminentemente preventivo. Os programas de compliance significam, em síntese, "as medidas mediante as quais as empresas pretendem assegurar-se que sejam cumpridas as regras vigentes para elas e para seu pessoal, e que, por igual, se descubram e se sancionem as eventuais infrações a tais regras" (DINIZ; SILVEIRA, 2015, p. 119).

Não à toa, a Lei Anticorrupção positivou, no art. $7^{\circ}$, inciso VIII ${ }^{176}$, que a presença do regime de integridade será um importante fator a ser levado em conta na ocasião da aplicação da penalidade a ser suportada pela pessoa jurídica, em caso de eventual incurso nos delitos da Lei. Se constatada a presença de um robusto e efetivo programa de compliance, a empresa infratora poderá ter a sua penalidade minorada ou, até mesmo, celebrar acordos de leniência.

Entre todos os mecanismos previstos pela Lei $n^{\circ}$ 12.846/13 para enfrentar a prática da corrupção no meio empresarial, merece destaque, no presente estudo, a previsão contida no artigo $14^{177}$, que dispõe sobre a possibilidade de a autoridade competente poder promover a desconsideração da personalidade jurídica da empresa no curso do processo

d) fraudar licitação pública ou contrato dela decorrente;

e) criar, de modo fraudulento ou irregular, pessoa jurídica para participar de licitação pública ou celebrar contrato administrativo;

f) obter vantagem ou benefício indevido, de modo fraudulento, de modificações ou prorrogações de contratos celebrados com a administração pública, sem autorização em lei, no ato convocatório da licitação pública ou nos respectivos instrumentos contratuais; ou

g) manipular ou fraudar o equilíbrio econômico-financeiro dos contratos celebrados com a administração pública;

V - dificultar atividade de investigação ou fiscalização de órgãos, entidades ou agentes públicos, ou intervir em sua atuação, inclusive no âmbito das agências reguladoras e dos órgãos de fiscalização do sistema financeiro nacional.

${ }^{176}$ Art. 7ํㅗ Serão levados em consideração na aplicação das sanções:

$[\ldots]$

VIII - a existência de mecanismos e procedimentos internos de integridade, auditoria e incentivo à denúncia de irregularidades e a aplicação efetiva de códigos de ética e de conduta no âmbito da pessoa jurídica;

${ }^{177}$ Art. 14. A personalidade jurídica poderá ser desconsiderada sempre que utilizada com abuso do direito para facilitar, encobrir ou dissimular a prática dos atos ilícitos previstos nesta Lei ou para provocar confusão patrimonial, sendo estendidos todos os efeitos das sanções aplicadas à pessoa jurídica aos seus administradores e sócios com poderes de administração, observados o contraditório e a ampla defesa. 
administrativo de responsabilização, com a consequente extensão das sanções às pessoas físicas dos sócios com poderes de direção e aos administradores.

A previsão contida no artigo 14 desafia a constitucionalidade da norma ao prever a possibilidade da Administração Pública desconsiderar a personalidade jurídica do ente coletivo, sem a presença de um pronunciamento jurisdicional. Ainda, desafia a própria lógica da Lei, que visa, primordialmente, sancionar a pessoa jurídica, e não as pessoas físicas que já estão sujeitas a outros diplomas vigentes no ordenamento jurídico brasileiro.

Assim, elucidadas as questões iniciais da Lei $\mathrm{n}^{\circ} 12.846 / 13$, tais como sua origem, previsões similares no direito nacional e comparado, bem como seus aspectos singulares, passa-se, em sequência, ao estudo mais aprofundado da questão da desconsideração da personalidade jurídica, explorando as teorias adotadas no ordenamento jurídico brasileiro para, ao final, investigar a validade da disposição contida no artigo 14 e sua congruência com os objetivos da Lei Anticorrupção.

\section{SEÇÃO II - DA TEORIA DA DESCONSIDERAÇÃO DA PERSONALIDADE JURÍDICA NO DIREITO BRASILEIRO}

\subsection{A DESCONSIDERAÇÃO DA PERSONALIDADE JURÍDICA: CONCEITO E FUNDAMENTOS}

A pessoa jurídica é um importantíssimo instrumento para o exercício e a viabilidade da atividade empresarial. Com sua constituição regular e a consequente consagração da autonomia patrimonial, os membros da sociedade podem desempenhar seus empreendimentos de risco sem que tenham, a priori, seus patrimônios particulares afetados pelos insucessos.

Contudo, ainda que seja essa a finalidade precípua da pessoa jurídica empresarial, não se pode olvidar que a autonomia patrimonial representa uma verdadeira faca de dois gumes: ao mesmo tempo que viabiliza a atividade comercial e mitiga os riscos dela decorrentes, pode representar um repudiável mecanismo de que seus membros podem valer-se para perpetrar fraudes e abusos de direito, escondidos na sombra do véu da personalidade jurídica.

Assim, quando a personalidade jurídica das sociedades tem seus propósitos desvirtuados devido a seu mau uso, não deve prevalecer o dogma da separação patrimonial 
entre a pessoa jurídica e seus membros, sob pena de dar guarida ao desvirtuamento do instituto e ao acobertamento das falcatruas.

A desconsideração da personalidade jurídica é, então, na definição de Marlon Tomazette (2014, p. 241), “a retirada episódica, momentânea e excepcional da autonomia patrimonial da pessoa jurídica, a fim de estender os efeitos de suas obrigações à pessoa física de seus titulares, sócios ou administradores, com o fim de coibir o desvio da função da pessoa jurídica perpetrado por estes”. Ainda, pontificam Pablo Stolze Gagliano e Rodolfo Pamplona Filho (2013, p. 276) que "a doutrina da desconsideração pretende o superamento episódico da personalidade jurídica da sociedade, em caso de fraude, abuso, ou simples desvio de função, objetivando a satisfação do terceiro lesado junto ao patrimônio dos próprios sócios, que passam a ter responsabilidade pessoal pelo ilícito causado".

Nessa esteira, desvirtuada a utilização da pessoa jurídica, deverá ser aplicada a teoria da desconsideração da personalidade jurídica, a fim de descartar a autonomia patrimonial no caso concreto e suspender a existência distinta entre a sociedade e os sócios que dela fizeram mau uso.

Importante salientar que, desconsiderada a personalidade societária, os efeitos das obrigações não se estenderão a todos os membros do quadro societário da sociedade, mas tão somente àqueles que cometeram os atos que desvirtuaram a finalidade do instituto. Assim, ensina Gladston Mamede (2012, p. 173) que a desconsideração "não licencia um amplo e indiscriminado acesso à comunidade societária, mas pressupõe a definição fundamentada de quem é o responsável pelo mau uso ou abuso da personalidade jurídica".

Outro ponto a se considerar é que a disregard doctrine não visa anular a personalidade jurídica da sociedade. O que se tem, na verdade, é uma relativização do instituto da personalidade jurídica e uma negação ao absolutismo desse direito. Sobre a relativização do instituto, preleciona Rubens Requião:

\footnotetext{
Ora, a doutrina da desconsideração nega precisamente o absolutismo do direito da personalidade jurídica. Desestima a doutrina esse absolutismo, perscruta através do véu que a encobre, penetra em seu âmago, para indagar de certos atos dos sócios ou do destino de certos bens. Apresenta-se, por conseguinte, a concessão da personalidade jurídica com um significado ou um efeito relativo, e não absoluto, permitindo a legítima penetração inquiridora em seu âmago (REQUIÃO, 1988, p. 70-71).
}

Ao Estado, então, é reconhecida a faculdade de verificar se o direito está sendo adequadamente usado e, nesse compasso, a personalidade jurídica passa a ser considerada, 
doutrinariamente, um direito relativo, permitindo ao juiz penetrar o véu da personalidade para coibir os abusos ou condenar a fraude através de seu uso.

E diferente não poderia ser. $\mathrm{O}$ que se pretende, com a aplicação da teoria, é desconsiderar a existência distinta entre os sócios e a sociedade de maneira episódica, para adequar a pessoa jurídica aos fins pelos quais foi criada. A desconsideração absoluta da personalidade jurídica implicaria na inviabilização da atividade empresarial, o que estaria em completo descompasso com os princípios que regem a Ordem Econômica e Financeira na Constituição Federal de 1988.

Por fim, há que ressaltar-se, também, que a aplicação da teoria em questão é medida excepcionalíssima, dada a inegável importância das pessoas jurídicas para as transações comerciais. Dessa maneira, apenas sacrifica-se a autonomia patrimonial das companhias quando comprovado, cabalmente, o desvio no uso da pessoa jurídica. Nesse diapasão, ressalta Marlon Tomazette:

\begin{abstract}
A personificação das sociedades é dotada de um altíssimo valor para o ordenamento jurídico e inúmeras vezes entra em conflito com outros valores, como a satisfação dos credores. A solução de tal conflito se dá pela prevalência do valor mais importante. O progresso e o desenvolvimento econômico proporcionados pela pessoa jurídica são mais importantes que a satisfação individual de um credor. Logo, deve normalmente prevalecer a personificação (TOMAZETTE, 2013, p. 240).
\end{abstract}

Assim, o fato de as sociedades mercantis personificadas representarem um importante vetor para o desenvolvimento econômico afasta, por completo, a ideia de que a aplicação da teoria da desconsideração da personalidade jurídica deve ser utilizada deliberadamente. A medida em questão é excepcional e deve ater-se às exigências e circunstâncias do caso concreto, bem como preencher os requisitos previstos em lei para sua correta aplicação.

\title{
2.2 AS TEORIAS DA DESCONSIDERAÇÃO DA PERSONALIDADE JURÍDICA
}

Para Rubens Requião (1988, p. 71), a aplicação da teoria da desconsideração da personalidade jurídica prescinde de fundamentos legais expressos, pois, na visão do autor, o Estado tem o direito de retirar o privilégio da personalidade jurídica quando o instituto é indevidamente usado, por imperativos de justiça.

Muito embora a teoria prescinda de lei expressa para sua aplicação, há que destacar-se que esta deve estar ancorada na correta fundamentação. Contudo, há divergências 
doutrinárias sobre quais seriam os requisitos e os fundamentos para aplicação da técnica em estudo, surgindo na doutrina duas teorias: a Teoria Menor e a Teoria Maior.

\subsubsection{Teoria Menor}

Na lição de Fábio Ulhôa Coelho, há a menção a uma corrente doutrinária que afirma que não existem requisitos específicos para a aplicação da desconsideração da personalidade jurídica (COELHO, 2006, apud, TOMAZETTE, 2014, p. 247-248). Tal corrente, denominada pela doutrina como "Teoria Menor", sustenta que o requisito primordial para afastar-se a autonomia patrimonial de uma sociedade é a prova da insolvabilidade, prescindindo da comprovação do uso indevido da pessoa jurídica.

No Direito Brasileiro, a aplicação da teoria menor foi acolhida na legislação trabalhista, consumerista e ambiental, sob o fundamento de que as relações jurídicas tuteladas por estes diplomas guardam certo desequilíbrio, o que legitimaria a aplicação da desconsideração pela simples frustração do credor em ver seu crédito adimplido. Inclusive, o Superior Tribunal de Justiça (STJ) tem um relevante precedente jurisprudencial sobre o tema, que foi objeto do Recurso Especial n ${ }^{\circ}$ 279.273/SP. Aquela corte decidiu, por apertada maioria, que "a teoria menor da desconsideração, acolhida em nosso ordenamento jurídico excepcionalmente no Direito do Consumidor e no Direito Ambiental, incide com a mera prova de insolvência da pessoa jurídica para o pagamento de suas obrigações, independentemente da existência de desvio de finalidade ou de confusão patrimonial" (BRASIL, 2004). Contudo, ainda que o STJ já tenha externado o seu entendimento acerca da matéria, a aplicação da teoria menor encontra fortes críticas na doutrina.

Para o professor Fábio Ulhôa Coelho, a aplicação da teoria menor é incorreta e reflete a crise do princípio da autonomia patrimonial das sociedades empresárias, pois “[...] nela, adota-se o pressuposto de que o simples desatendimento de crédito titularizado perante uma sociedade, em razão da insolvabilidade ou falência desta, seria suficiente para a imputação de responsabilidade aos sócios ou acionistas" (2014, p. 70).

No mesmo sentido vai o posicionamento de Marlon Tomazette, ao preconizar que "[...] tal teoria praticamente ignora a ideia de autonomia patrimonial das pessoas jurídicas e não se coaduna com a própria origem de aplicação da teoria da desconsideração.”, pois “[...] ao contrário de proteger, a teoria menor acaba por minar a existência da autonomia 
patrimonial, em nada favorecendo aqueles que se dignam a exercer atividades econômicas" (2014, p. 248).

Dessa maneira, o que se depreende é que a aplicação da teoria menor, dissociada da prova do desvirtuamento da pessoa jurídica e fundada unicamente na frustração dos credores, não parece razoável. Ainda que considerada aplicável a determinados ramos do direito, é temeroso o descarte da autonomia patrimonial, com base unicamente na insatisfação dos créditos.

\subsubsection{Teoria Maior}

A teoria maior, ao contrário da teoria menor, preceitua que "não basta o descumprimento de uma obrigação por parte da pessoa jurídica, é necessário que tal descumprimento decorra do desvirtuamento da sua função" (TOMAZETTE, 2014, p. 246).

Nesse contexto, a teoria maior prestigia a personificação das sociedades como um instrumento legítimo de destaque patrimonial e reforça a premissa de que o seu descarte deve ser realizado excepcionalmente. Vale dizer: para a referida teoria, a desconsideração da personalidade jurídica só pode ser efetivada quando o uso da pessoa jurídica se afasta dos fins pelos quais foi criada, mediante a comprovação da confusão patrimonial ou do abuso de direito caracterizado pela fraude ou desvio de finalidade.

O Código Civil Brasileiro, seguindo os fundamentos da teoria maior, consagrou as suas premissas no seu artigo 50, o qual dispõe, in verbis:

Art. 50. Em caso de abuso da personalidade jurídica, caracterizado pelo desvio de finalidade, ou pela confusão patrimonial, pode o juiz decidir, a requerimento da parte, ou do Ministério Público quando lhe couber intervir no processo, que os efeitos de certas e determinadas relações de obrigações sejam estendidos aos bens particulares dos administradores ou sócios da pessoa jurídica.

Do dispositivo extrai-se que duas são as hipóteses autorizadoras para aplicação do instituo: a confusão patrimonial e o abuso de direito. Na doutrina, no entanto, existem divergências sobre a necessidade da presença do intuito fraudulento no uso da pessoa jurídica para se aplicar o referido dispositivo, subdividindo a teoria em duas correntes: a Teoria Maior Objetiva e a Teoria Maior Subjetiva. 


\subsubsection{Teoria Maior Objetiva}

A teoria maior objetiva, encabeçada por Fábio Konder Comparato (COMPARATO, 1983, apud, TOMAZETTE, 2014, p. 247), aduz que é a existência de confusão patrimonial o requisito primordial hábil a legitimar a aplicação da desconsideração da personalidade jurídica. Para o autor, o embaralhamento das obrigações da sociedade com as relativas aos patrimônios dos sócios ou administradores caracteriza abuso no uso da personalidade jurídica, pois representa um rompimento com os princípios que dão sustentação ao artifício da pessoa jurídica.

Nessa linha, exemplifica Fábio Ulhôa Coelho que “[...] se a partir da escrituração contábil, ou da movimentação de contas de depósito bancário, percebe-se que a sociedade paga dívidas do sócio, ou este recebe créditos dela, ou o inverso, então não há suficiente distinção, no plano patrimonial, entre as pessoas" (2014, p. 67). Assim, para a formulação objetiva da teoria da desconsideração, basta a inexistência de separação clara entre o patrimônio da pessoa jurídica e o patrimônio dos sócios ou administradores para se caracterizar uma forma de abuso no uso da pessoa jurídica.

Ressalta o professor, ainda, que, ao eleger a confusão patrimonial como o pressuposto da desconsideração, a linha objetivista quis facilitar a tutela dos interesses de credores ou terceiros lesados pelo uso fraudulento do princípio da autonomia (COELHO, 2014, p. 67) pois, por meio da prova da confusão patrimonial, pode-se chegar à conclusão de que os patrimônios dos sócios e da sociedade não estão devidamente destacados, o que caracterizaria, de certa maneira, uma forma fraudulenta de uso da personalidade jurídica.

Para Pablo Stolze Gagliano e Rodolfo Pamplona Filho, o Código Civil se filiou à corrente objetivista ao prescindir da demonstração do elemento anímico - a intenção de fraudar a lei - para desconsiderar a personalidade jurídica (2013, p. 281). No mesmo sentido vai a orientação jurisprudencial do Superior Tribunal de Justiça (BRASIL, 2009).

Contudo, não é unânime na doutrina a adoção desta vertente. Para alguns autores, a confusão patrimonial não exaure todas as possibilidades de desconsideração da personalidade jurídica e não gera a presunção de que houve abuso no uso da personalidade jurídica pela simples demonstração da confusão entre os patrimônios dos sócios e da sociedade. 


\subsubsection{Teoria Maior Subjetiva}

A teoria maior subjetiva, ao revés da formulação objetiva, adota como pressuposto fundamental para a aplicação da desconsideração da personalidade societária "o desvio da função da pessoa jurídica, que se constata na fraude e no abuso de direito relativos à autonomia patrimonial" (TOMAZETTE, 2013, p. 250). Ou seja, para a concepção subjetiva da teoria maior, é preciso ter caracterizada a intenção de desviar a finalidade da pessoa jurídica por meio da fraude ou do abuso de direito, desde que perpetrados por meio do uso indevido da autonomia patrimonial.

Tal vertente parece se amoldar com maior precisão às premissas da doutrina da desconsideração da personalidade jurídica, já que a concepção objetiva dá margem à interpretação de que a simples demonstração da confusão patrimonial, ainda que dissociada da finalidade de burlar a legislação, autorizaria a aplicação da técnica em estudo.

Em crítica à formulação objetiva, Marlon Tomazette adverte que ainda é extremamente comum, na realidade econômica brasileira, a utilização de bens pessoais dos sócios em sociedades para a consecução da atividade empresarial - o que seria, em tese, uma forma de confusão patrimonial - só que, nem sempre, com a finalidade de desviar a função da sociedade comercial (2014, p. 266). Nesses casos, a visão pregada pela teoria objetiva autorizaria o afastamento do manto da personalidade, ainda que o embaralhamento dos bens não se tenha dado com o intuito de prejudicar terceiros ou fraudar credores.

Por isso, se vista de outro modo a exegese do artigo 50 do Código Civil, e em conformidade com os preceitos da disregard doctrine, tem-se que a presença da confusão patrimonial só poderia autorizar a aplicação do instituto desde que a sua configuração guarde relação com o intuito de desvirtuar a personalidade jurídica, não bastando a demonstração da simples confusão dos patrimônios. Diferente é, neste viés interpretativo, a hipótese em que o sócio se utiliza da proteção dada pela autonomia patrimonial da sociedade para misturar seus débitos e fraudar seus credores pessoais, pois aí sim restaria configurada a manifestação fraudulenta da confusão patrimonial por meio do uso abusivo da personalidade societária.

Desta feita, diante da divergência doutrinária exposta, optou-se, para os fins do presente estudo, por adotar a concepção subjetiva da teoria maior na análise do artigo 50 do Código Civil, de modo a considerar indispensável a presença da intenção de desviar as 
finalidades da companhia por meio do uso abusivo da personalidade jurídica. Nesta mesma orientação vai o posicionamento de renomados autores ${ }^{178}$.

Prosseguindo na análise da linha subjetiva, extrai-se que são dois os requisitos alternativos hábeis a autorizar a aplicação da técnica em estudo: a constatação da fraude ou do abuso de direito, desde que relativos à autonomia patrimonial.

Sobre a fraude, aponta Alexandre Couto Silva que esta é "a distorção intencional da verdade com o intuito de prejudicar terceiros" (SILVA, 1999, apud, TOMAZETTE, 2014, p. 250). Nesse sentido, o intuito fraudulento pode ser constatado quando verificado que os dirigentes da pessoa jurídica se aproveitaram da personalidade jurídica para burlar a lei e prejudicar credores, em benefício do próprio fraudador ou de terceiro.

Para a sua caracterização, Gladston Mamede ressalta a indispensabilidade da presença do elemento doloso. Nas palavras do autor, "o uso da pessoa jurídica para a prática consciente de atos ilícitos não se amolda à função social do instituto, mas é indispensável o dolo. A simples prática de ato ilícito pela sociedade não é hipótese de despersonificação" (2012, p. 159).

Com base nessa premissa, cita o autor o entendimento da Segunda Turma do Superior Tribunal de Justiça, externado no julgamento do Agravo de Instrumento $\mathrm{n}^{\mathbf{o}}$ 527.857/MG, o qual entendeu pela impossibilidade de ignorar a personalidade jurídica da sociedade pelo simples fato da demandada não ter realizado o recolhimento de um tributo. $\mathrm{Na}$ hipótese, a referida Corte considerou que não foi comprovada a prática de atos que pudessem ser interpretados como excessivos ou contrários à lei, como contrato social ou estatutos e, por isso, não haveria que falar-se na aplicação da desconsideração da personalidade jurídica.

Já no que toca ao abuso de direito, não se vislumbra, a priori, o uso da sociedade como uma forma de tramar contra o direito do credor. $\mathrm{O}$ ato abusivo surge do inadequado uso de um direito, ainda que a finalidade de prejudicar outrem seja estranha ao agente (REQUIÃO, 1988, p. 73).

$\mathrm{Na}$ lição de Rubens Requião, o ato abusivo é aquele que se mostra em conformidade com a lei, só que com a sua finalidade deturpada, atentando contra o próprio direito. Ainda, distingue o professor entre o abuso de direito e a fraude, argumentando que:

Ora, como se vê, não há por que confundir a teoria do abuso de direito com a do ato ilícito, ou, mais precisamente, com a fraude. Considera-se ato fraudulento como o conceituam os revisores do Projeto de Código de Obrigações, no art. 67, “o negócio

178 Fábio Ulhôa Coelho, Gladston Mamede, Marlon Tomazette e Rubens Requião defendem a imprescindibilidade do elemento anímico para a legitimação da disregard doctrine. 
jurídico tramado para prejudicar credores, em benefício do declarante ou de terceiro". No abuso de direito não existe, propriamente, trama contra o direito de credor, mas surge do inadequado uso de um direito, mesmo que seja estranho ao agente o propósito de prejudicar o direito de outrem (REQUIÃO, 1988, p. 73).

Por fim, frisa Gladston Mamede (2012, p. 160) que a pessoa jurídica, por natureza, é um ser finalístico que deve ser utilizada para o cumprimento de certo objeto, conforme o que foi delimitado em seu ato constitutivo. Para o autor, se o ente coletivo é utilizado para praticar atos em desconformidade com aquilo que foi disciplinado em seu contrato social e às normas e princípios gerais do direito, deve afastar-se o manto da personificação para responsabilizar os verdadeiros responsáveis pelos atos abusivos.

\title{
SEÇÃO III - A DESCONSIDERAÇÃO DA PERSONALIDADE JURÍDICA NA LEI 12.846/13
}

\subsection{REQUISITOS E APLICAÇÃO DA TEORIA DA DESCONSIDERAÇÃO DA PERSONALIDADE JURÍDICA NA LEI 12.846/13}

A Lei Anticorrupção das Pessoas Jurídicas inovou ao incorporar, no ordenamento jurídico, o permissivo legal de que, no curso do processo administrativo de responsabilização, poderá a Administração Pública desconsiderar a personalidade societária do ente coletivo com a finalidade de estender os efeitos das sanções contidas na Lei às pessoas físicas dos sócios com poderes de administração e aos administradores.

Nesse sentido, dispõe o artigo 14 da Lei, in verbis:

\begin{abstract}
Art. 14. A personalidade jurídica poderá ser desconsiderada sempre que utilizada com abuso do direito para facilitar, encobrir ou dissimular a prática dos atos ilícitos previstos nesta Lei ou para provocar confusão patrimonial, sendo estendidos todos os efeitos das sanções aplicadas à pessoa jurídica aos seus administradores e sócios com poderes de administração, observados o contraditório e a ampla defesa.
\end{abstract}

$\mathrm{O}$ artigo 14 parece se amoldar à teoria maior subjetiva, ao ir na mesma direção dada pelo artigo 50 do Código Civil, exigindo a intenção de usar fraudulentamente o instituto da pessoa jurídica (TOMAZETTE, 2013, p. 275). Da interpretação do dispositivo, depreendese que será autorizada a aplicação da disregard doctrine, no curso do processo administrativo de responsabilização, quando ficar demonstrado que a pessoa jurídica foi utilizada com abuso de direito para facilitar, encobrir ou dissimular a prática de atos ilícitos ou, até mesmo, para provocar a confusão patrimonial. 
Embora a redação do artigo 14 da Lei $n^{\circ} 12.846 / 13$ não seja muito clara quanto aos limites para sua aplicação, é certo que a extensão das sanções administrativas previstas no artigo $6^{\circ}$ da Lei ${ }^{179}$ não afetará, indistintamente, todos os membros que compõem a gerência da comunidade societária. A desconsideração, conforme já foi abordado neste estudo, somente atinge aqueles que efetivamente deliberaram pela prática do ato ilícito ou que dele se beneficiaram (MAMEDE, 2012, p. 173).

Nesse ponto, ressalta-se que a incriminação do sócio-administrador dependerá da prova inequívoca de que o ilícito cometido está intrinsecamente ligado ao mau uso da personalidade jurídica. Nesse contexto, Gilson Dipp e Manoel L. Volkmer de Castilho ensinam:

[...] As limitações da desconsideração da pessoa jurídica estão relacionadas diretamente com a utilização ilícita dessa forma de constituição de modo que haverá necessidade de demonstrar que o mau uso ou abuso da forma societária é ou está inerente ao ilícito contra a administração pública (DIPP; DE CASTILHO, 2016, p. 67)

Alternativamente, a prova da confusão patrimonial, desde que relacionada com o mau uso da pessoa jurídica na prática do ato lesivo à Administração Pública, também poderá autorizar o afastamento do manto da personalidade jurídica para a responsabilização dos sócios. É certo que a confusão patrimonial entre os patrimônios do sócio e da pessoa jurídica deve ser fruto desse desvirtuamento da personalidade jurídica, o que não é cogitado no viés interpretativo dado pela teoria maior objetiva ${ }^{180}$.

Ainda, é importante apontar que existem significativas diferenças entre a desconsideração da personalidade jurídica e a responsabilização de sócios e administradores na legislação em exame. A distinção, para Marçal Justen Filho reside, justamente, no campo da autoria da infração.

Ensina o professor que o sancionamento, pela prática, do ato ilícito e a responsabilidade pelos efeitos da prática de ato ilícito são coisas totalmente distintas e não se confundem. A prática da ilicitude sujeita o agente infrator à sanção, pois o sujeito é punido

\footnotetext{
179 Art. 60 $\mathrm{Na}$ esfera administrativa, serão aplicadas às pessoas jurídicas consideradas responsáveis pelos atos lesivos previstos nesta Lei as seguintes sanções:

I - multa, no valor de $0,1 \%$ (um décimo por cento) a $20 \%$ (vinte por cento) do faturamento bruto do último exercício anterior ao da instauração do processo administrativo, excluídos os tributos, a qual nunca será inferior à vantagem auferida, quando for possível sua estimação; e

II - publicação extraordinária da decisão condenatória.

${ }^{180}$ Sobre o assunto, confira o item "2.2.2.2 Teoria Maior Subjetiva” deste estudo. 
porque praticou determinada conduta, enquanto que, na responsabilização, o sujeito somente poderá arcar com os efeitos patrimoniais da conduta reprimida, visto que não se pode estender a sanção propriamente dita ao responsável, em razão do princípio da intranscendência das penas previsto no artigo $5^{\circ}$, inciso XLV da Constituição Federal ${ }^{181}$.

Nessa linha, tem-se que quando configurado que o sócio-administrador, ou dirigente da sociedade, tiver utilizado a pessoa jurídica com intuito fraudulento, em nítida afronta à Lei, a autoria da infração será a ele imputada, juntamente com a pessoa jurídica. Quando deturpado o uso da personalidade jurídica da sociedade, restará configurado que o princípio da existência distinta entre a pessoa jurídica e o sócio foi prejudicado, visto que ambos foram elementos imprescindíveis para a prática do ilícito.

Nesse diapasão, ressalta o professor Marçal Justen Filho que a solução dada pelo artigo 14 é muito distinta daquela conferida pela responsabilidade objetiva e solidária das sociedades controladoras, controladas, coligadas e consorciadas, prevista no artigo $4^{\circ}, \S 2^{\circ}$, da Lei $n^{\circ} 12.846 / 13^{182}$. Para o autor:

\begin{abstract}
Ou seja, a desconsideração societária é prevista formalmente na Lei $\mathrm{n}^{\circ} 12.846$ como uma solução jurídica distinta daquela estabelecida no art. $4^{\circ}$, $2^{\circ}$, do mesmo diploma. A responsabilidade da sociedade controladora, controlada ou coligada pelos efeitos patrimoniais de atos de corrupção praticados por agentes de outras sociedades não se confunde com a desconsideração da personalidade societária.

Justamente por isso, o art. 14 determina que, nas hipóteses de desconsideração, todas as sanções pertinentes à autoria do ilícito serão impostas também aos sócios e administradores. Assim se passará porque a conduta ilícita será atribuída também a eles, hipótese muito distinta daquela contemplada no art. $4^{\circ}, \S 2^{\circ}$, da mesma Lei. (JUSTEN FILHO, 2016, p. 570).
\end{abstract}

Esclarecidos esses pontos iniciais, passa-se à análise dos outros aspectos quem têm levantado fortes debates na doutrina e dúvidas quanto à aplicação da disregard doctrine no âmbito da legislação em estudo. Para tanto, optou-se por centralizar a análise na

\footnotetext{
${ }^{181}$ Art. $5^{\circ}$ Todos são iguais perante a lei, sem distinção de qualquer natureza, garantindo-se aos brasileiros e aos estrangeiros residentes no País a inviolabilidade do direito à vida, à liberdade, à igualdade, à segurança e à propriedade, nos termos seguintes:

(...)

XLV - nenhuma pena passará da pessoa do condenado, podendo a obrigação de reparar o dano e a decretação do perdimento de bens ser, nos termos da lei, estendidas aos sucessores e contra eles executadas, até o limite do valor do patrimônio transferido;

${ }^{182}$ Art. 4o Subsiste a responsabilidade da pessoa jurídica na hipótese de alteração contratual, transformação, incorporação, fusão ou cisão societária.

(...)

$\S 2^{\mathrm{o}}$ As sociedades controladoras, controladas, coligadas ou, no âmbito do respectivo contrato, as consorciadas serão solidariamente responsáveis pela prática dos atos previstos nesta Lei, restringindo-se tal responsabilidade à obrigação de pagamento de multa e reparação integral do dano causado.
} 
possibilidade da técnica em questão ser aplicada pela própria Administração Pública e sobre a constitucionalidade de tal previsão legal.

\subsection{A DESCONSIDERAÇÃO DA PERSONALIDADE JURÍDICA NA ESFERA ADMINISTRATIVA}

É certo que a positivação da teoria da desconsideração da personalidade jurídica na Lei Anticorrupção inaugurou uma previsão normativa que não existia antes no ordenamento jurídico brasileiro: a possibilidade expressa de que a Administração Pública possa estender as sanções administrativas aos dirigentes e sócios com poderes de administração.

No entanto, é importante destacar que há muito a doutrina tem defendido a possibilidade de a Administração Pública aplicar a medida em questão, em razão das peculiaridades próprias do regime jurídico administrativo.

Para Maria Sylvia Zanella Di Pietro (2015, p. 60-63), o regime jurídico pelo qual a Administração Pública está submetida resume-se em duas palavras: prerrogativas e sujeições. Na visão da autora, a Administração detém prerrogativas na medida em que, no seu atuar, pode-se valer da autoexecutoriedade e da autotutela dos atos administrativos, bem como das medidas de intervenção do Estado na propriedade, mas também está sujeita a princípios constitucionais, como o da moralidade administrativa, da legalidade, obrigatoriedade e da publicidade que orientam-na.

A coexistência das prerrogativas, de um lado, e das sujeições, de outro, colocam a Administração em posição de supremacia perante o particular, mas com atuação restrita à observância de determinados fins e princípios. Assim, as prerrogativas e sujeições se justificam na exata medida em que ambas condicionam e auxiliam a atuação da Administração Pública em busca da satisfação do interesse público.

Com base nisso, parte da doutrina tem sustentado a possibilidade da desconsideração administrativa da pessoa jurídica, mesmo antes do advento da Lei $\mathrm{n}^{\mathbf{o}}$ 12.846/13. A Administração Pública, na busca pela satisfação da sua missão constitucional, pode, em atenção aos princípios que regem a sua atuação, afastar a personalidade jurídica de um determinado ente coletivo, visando coibir a prática de ilícitos em detrimento do Poder Público. 
Dentre os princípios que endossam essa possibilidade, Diógenes Gasparini (2007, p. 08-09) invoca os seguintes: o princípio do dever-poder de agir, o princípio do interesse público e o princípio da moralidade administrativa.

Pelo princípio do dever-poder de agir, ensina Hely Lopes Meirelles que "[...] o poder tem para o agente público o significado de dever para com a comunidade e para com os indivíduos, no sentido de que quem o detém está sempre na obrigação de exercitá-lo" (2003, p. 101). Nesse contexto, a Administração Pública, em atenção ao princípio constitucional da eficiência, não pode se abster da prática de um ato quando, em um determinado caso concreto, sua atuação é requisitada para a satisfação do interesse público.

Quanto ao princípio do interesse público, a doutrina entende que é aquele que impõe obediência à Administração Pública, no âmbito de sua atuação. Para Diógenes Gasparini (2007, p. 09), a Administração pratica atos e comportamentos exclusivamente voltados a alcançar o interesse público, pois é a direção única de quaisquer de suas atuações. Complementa Celso Antônio Bandeira de Mello indicando que o interesse público, além de representar um verdadeiro norte à atuação administrativa, é indisponível, visto que "as pessoas administrativas não têm, portanto, disponibilidade sobre os interesses públicos confiados à sua guarda e realização"(2004, p. 69).

Quanto ao princípio da moralidade administrativa, este encontra previsão expressa no artigo 37 da Constituição Federal ${ }^{183}$. Para Maria Sylvia Zanella Di Pietro, o referido princípio assume uma obediência bilateral e que deve ser obrigatoriamente observado tanto pelo administrado, quanto pelo administrador. Nas palavras da autora,

[...] sempre que em matéria administrativa se verificar que o comportamento da Administração ou do administrado que com ela se relaciona juridicamente, embora em consonância com a lei, ofende a moral, os bons costumes, as regras de boa administração, os princípios de justiça e de equidade, a ideia comum de honestidade, estará havendo ofensa ao princípio da moralidade (DI PIETRO, 2015, p. 79).

Diante da conjugação destes princípios com a constatação dos pressupostos fundamentais da disregard doctrine, autores como Marçal Justen Filho já defendiam sua aplicação em sede de contratações públicas, mesmo antes do advento da Lei Anticorrupção. Para o mencionado autor, o artigo 77 da Lei de Licitações e Contratações Públicas (Lei no

\footnotetext{
${ }^{183}$ Art. 37. A administração pública direta e indireta de qualquer dos Poderes da União, dos Estados, do Distrito Federal e dos Municípios obedecerá aos princípios de legalidade, impessoalidade, moralidade, publicidade e eficiência e, também, ao seguinte (...).

Revista de Direito da Administração Pública, ISSN 2595-5667, a. 2, v. 1, n. 3, julho-dezembro, 2017, p. 97
} 
$8.666 / 93)^{184}$, por meio de uma interpretação extensiva, autoriza a aplicação da desconsideração da personalidade jurídica através de ato administrativo, quando constatado no caso concreto que a empresa descumpriu responsabilidades previstas em contrato administrativo, por meio de fraude ou abuso no uso da pessoa jurídica (JUSTEN FILHO, 2014, p. 1.084)

Então, quando constatado, em um caso concreto, que uma sociedade empresária de fachada é constituída tão somente para fraudar a lei ou contornar sanções impostas a outra criada pelos mesmos sócios, com idênticos objetivos sociais, com sede e funcionamento no mesmo local, utilizando ambas as mesmas instalações, bens e equipamentos e empregados, poderia a Administração Pública, por meio do seu regime jurídico e em atenção aos princípios do poder-dever, interesse público e da moralidade administrativa, legitimar a aplicação da disregard doctrine através de ato administrativo.

No entanto, muito embora a aplicação da teoria encontre ampla aceitação entre autores do direito administrativo, é necessário destacar que ainda há forte resistência por parte de uma parcela da doutrina no que tange a sua aplicação na seara administrativa. Há autores que entendem que a desconsideração da personalidade jurídica só poderia ser aplicada pelo Poder Judiciário, tal como preconizam os artigos 50 do Código Civil e 28 do Código de Defesa do Consumidor ${ }^{185}$, que aduzem, expressamente, que somente o juiz poderá decretar a medida.

Entre os autores que sustentam essa tese está o professor Modesto Carvalhosa. Para o jurista, a decretação da desconsideração da personalidade jurídica no bojo de um processo administrativo, tal como prevê a Lei no 12.846/13, fere o Estado Democrático de Direito, na medida em que se dá à Administração uma competência reservada ao Poder Judiciário. Nas palavras do autor:

[...] É, sobretudo, irônica a parte final do aberrante dispositivo contido no art. 14 ao preceituar que a pessoa jurídica indigitada terá, perante a autoridade administrativa processante, o pleno direito ao contraditório e à ampla defesa (art. 14).

Trata-se de norma não escrita pela sua absoluta inconstitucionalidade - usurpação de competência judiciária - e pela insanável contradição à finalidade da presente Lei (CARVALHOSA, 2015, p. 364).

\footnotetext{
${ }^{184}$ Art. 77. A inexecução total ou parcial do contrato enseja a sua rescisão, com as consequências contratuais e as previstas em lei ou regulamento.

185 Art. 28. O juiz poderá desconsiderar a personalidade jurídica da sociedade quando, em detrimento do consumidor, houver abuso de direito, excesso de poder, infração da lei, fato ou ato ilícito ou violação dos estatutos ou contrato social. A desconsideração também será efetivada quando houver falência, estado de insolvência, encerramento ou inatividade da pessoa jurídica provocados por má administração. 
Contudo, em que pese o respeitável entendimento dessa corrente doutrinária, há que se ter em mente que a hermenêutica a ser empregada no caso da desconsideração da personalidade jurídica, na Lei $\mathrm{n}^{\circ} 12.846 / 13$, deve ser feita em atenção ao escopo fundamental dos princípios constitucionais que regem a Administração Pública.

Não parece razoável elencar a cláusula de reserva de jurisdição como um obstáculo intransponível à aplicação da teoria da desconsideração societária pela Administração Pública. No entanto, não se deixa de observar que a reserva de jurisdição é, de fato, uma garantia fundamental a ser observada, visto que não se pode usurpar a competência do Poder Judiciário para aplicar medidas que a ele foram reservadas por força de norma constitucional.

Contudo, vislumbra-se que, para o correto zelo da moralidade administrativa, não é demais admitir que a disregard doctrine representa um importante instrumento para uma eficiente proteção do interesse público, visto que se dá maior cumprimento ao princípio constitucional da eficiência, que pauta a finalidade dos atos administrativos. Assim, não se pode estender a exigência de autorização judicial quando aquele que foi lesado pelo uso fraudulento e abusivo da pessoa jurídica é a própria Administração Pública.

Não se pode invocar o artigo 50 do Código Civil e tampouco o artigo 28 do Código de Defesa do Consumidor para legitimar o argumento de que a Administração estaria impedida de aplicar a técnica em questão e que tal possibilidade estaria reservada ao Poder Judiciário. Aqui, é necessário ter em mente que se está diante de vínculos e relações jurídicas regidas por regimes jurídicos distintos: o direito público e o direito privado.

Os vínculos jurídicos de direito privado são regidos, por excelência, por convenções particulares que estabelecem relações obrigacionais próprias de credores e devedores, pois tal ramo do direito é marcado, justamente, por regular as relações dos indivíduos entre si (GAGLIANO; PAMPLONA FILHO, 2013, p. 76). Nesse prisma, o uso abusivo da personalidade jurídica, por meio da fraude ou do abuso de direito, somente poderá ser averiguado pelo Estado-Juiz, que, agindo em observância ao princípio da imparcialidade, decreta a medida mediante pronunciamento jurisdicional.

É necessário ressaltar que as relações reguladas pelo Direito Civil e pelo Direito do Consumidor partem do pressuposto de que as partes são particulares e que, no âmbito dessas obrigações pactuadas, agem como tal. Há uma visível horizontalidade na relação jurídica, porquanto não se vislumbra uma nítida posição de supremacia jurídica legitimada pelo Direito. Complementando este raciocínio, ensina Luciano Chaves de Farias: 


\begin{abstract}
Assim, tem-se que o agente da desconsideração da personalidade jurídica na seara administrativa não é o juiz. A explicação lógica para a necessidade de decisão judicial nas esferas consumerista e cível reside no fato da existência de relações jurídicas de Direito privado, caracterizadas pela horizontalidade, não podendo uma das partes, unilateralmente, impor obrigações ou constituir direitos em desfavor da outra. Na esfera administrativa, a realidade é bem distinta. As reações jurídicas não são caracterizadas pela horizontalidade, existem as conhecidas cláusulas exorbitantes, a indisponibilidade do interesse público e sua prevalência (supremacia) sobre o interesse privado da outra parte. Por isso, é plenamente possível conceber a dispensabilidade do magistrado na aplicação da teoria na seara administrativa (FARIAS, 2007, p. 44).
\end{abstract}

Ao revés dessas relações estão aquelas tipicamente reguladas pelo Direito Público. Quando uma das partes contrata ou se vê presa a um vínculo jurídico com a Administração Pública, esta passa a se submeter ao poder de império da Administração, em razão das suas prerrogativas e sujeições (DI PIETRO, 2014, p. 269). Tais relações não são marcadas pela horizontalidade, e prova disso são as possibilidades de imposições de obrigações unilaterais e as cláusulas exorbitantes no âmbito das contratações públicas.

Portanto, o que se percebe é que estando a Administração Pública em nítida posição vertical legitimada pelo seu regime jurídico administrativo, a figura do Poder Judiciário se torna, muitas vezes, desnecessária para a tutela do interesse público. Conforme já foi afirmado, a Administração pauta sua atuação em obediência ao princípio indisponível do interesse público, razão pela qual a desconsideração da personalidade jurídica, no curso do processo administrativo, prescindirá de pronunciamento jurisdicional.

\title{
3.2.1 DO POSICIONAMENTO DA JURISPRUDÊNCIA
}

\subsection{I.1 O posicionamento do Superior Tribunal de Justiça (STJ)}

A respeito da desconsideração administrativa da pessoa jurídica, o Superior Tribunal de Justiça já se posicionou favorável a sua aplicação no bojo dos certames licitatórios, mesmo antes do advento da Lei n $12.846 / 13$.

No julgamento do Recurso Ordinário no 15.166/BA, a Corte Superior externou o entendimento de que a Administração Pública pode afastar o manto da personalidade jurídica da sociedade empresária que foi utilizada como manobra para o cometimento de fraudes em licitações, em razão dos princípios constitucionais da moralidade e da indisponibilidade do interesse público que regem a atuação administrativa. 
No caso levado à apreciação da Corte, a sociedade desconsiderada havia sido constituída pelos mesmos sócios de outra companhia que já havia sido penalizada com a sanção de declaração de inidoneidade prevista na Lei $n^{\circ}$ 8.666/93. A constituição da nova sociedade evidenciou que as pessoas físicas estavam se utilizando da nova entidade para burlar as sanções já aplicadas, se utilizando da personalidade jurídica fraudulentamente para realizar novas contratações com o Poder Público.

Assim, diante da nítida afronta à lei perpetrada pelo uso abusivo da personalidade jurídica, a Administração Pública estendeu as penalidades aplicadas à pessoa jurídica aos sócios da nova companhia, por meio da aplicação da técnica da desconsideração da personalidade jurídica. $\mathrm{O}$ entendimento firmado em sede administrativa foi confirmado pelo STJ, conforme o que se extrai da ementa abaixo:

\begin{abstract}
ADMINISTRATIVO. RECURSO ORDINÁRIO EM MANDADO DE SEGURANÇA. LICITAÇÃO. SANÇÃO DE INIDONEIDADE PARA LICITAR. EXTENSÃO DE EFEITOS À SOCIEDADE COM O MESMO OBJETO SOCIAL, MESMOS SÓCIOS E MESMO ENDEREÇO. FRAUDE À LEI E ABUSO DE FORMA. DESCONSIDERAÇÃO DA PERSONALIDADE JURÍDICA NA ESFERA ADMINISTRATIVA. POSSIBILIDADE. PRINCÍPIO DA MORALIDADE ADMINISTRATIVA E DA INDISPONIBILIDADE DOS INTERESSES PÚBLICOS.

- A constituição de nova sociedade, com o mesmo objeto social, com os mesmos sócios e com o mesmo endereço, em substituição a outra declarada inidônea para licitar com a Administração Pública Estadual, com o objetivo de burlar a aplicação da sanção administrativa, constitui abuso de forma e fraude à Lei de Licitações Lei n. ${ }^{\circ}$ 8.666/93, de modo a possibilitar a aplicação da teoria da desconsideração da personalidade jurídica para estenderem-se os efeitos da sanção administrativa à nova sociedade constituída.

- A Administração Pública pode, em observância ao princípio da moralidade administrativa e da indisponibilidade dos interesses públicos tutelados, desconsiderar a personalidade jurídica de sociedade constituída com abuso de forma e fraude à lei, desde que facultado ao administrado o contraditório e a ampla defesa em processo administrativo regular.

- Recurso a que se nega provimento. (RMS 15.166/BA, Rel. Ministro CASTRO MEIRA, SEGUNDA TURMA, julgado em 07/08/2003, DJ 08/09/2003, p. 262) ${ }^{186}$.
\end{abstract}

Ainda, destacou o relator, Ministro Castro Meira, que a ausência de previsão legal expressa não pode ser considerada um obstáculo à Administração Pública, pois não se pode impor ao ente administrativo uma atuação que sacrifique o interesse público ou em desconformidade com o princípio da moralidade administrativa. Em seu voto, ressaltou o Ministro:

186 BRASIL. Superior Tribunal de Justiça. ROMS nº 15.166 - BA, Rel. Min. Castro Meira, julgado em 07/08/2003. 
Firmado o entendimento de que a Recorrente foi constituída em nítida fraude à lei e com abuso de forma, resta a questão relativa à possibilidade de desconsideração da personalidade jurídica, na esfera administrativa, sem que exista um dispositivo legal específico a autorizar a adoção dessa teoria pela Administração Pública.

$[\ldots]$

A ausência de norma específica não pode impor à Administração um atuar em desconformidade com o Princípio da Moralidade Administrativa, muito menos exigir-lhe o sacrifício dos interesses públicos que estão sob sua guarda. Em obediência ao Princípio da Legalidade, não pode o aplicador do direito negar eficácia aos muitos princípios que devem modelar a atuação do Poder Público.

Assim, permitir-se que uma empresa constituída com desvio de finalidade, com abuso de forma e em nítida fraude à lei, venha a participar de processos licitatórios, abrindo-se a possibilidade de que a mesma tome parte em um contrato firmado com o Poder Público, afronta aos mais comezinhos princípios de direito administrativo, em especial ao da Moralidade Administrativa e ao da Indisponibilidade dos Interesses Tutelados pelo Poder Público. [...] (BRASIL, 2003).

\subsection{I.2 O posicionamento do Supremo Tribunal Federal (STF)}

No tocante à questão da desconsideração da personalidade jurídica em sede administrativa, o Supremo Tribunal Federal ainda não se pronunciou, definitivamente, sobre a constitucionalidade da sua aplicação pela Administração Pública. Contudo, já foi levada à apreciação da Corte Suprema, em sede de tutela de urgência cautelar em mandado de segurança, a análise da constitucionalidade do ato administrativo emanado pelo Tribunal de Contas da União (TCU), que estendeu a sanção de suspensão do direito de licitar prevista no artigo $7^{\circ}$ da Lei $n^{\circ} 10.520 / 2002^{187}$ às pessoas físicas dos sócios, pelo fato de aquele órgão de contas ter entendido que a sociedade empresária foi utilizada como instrumento de fraude e abuso de direito.

No voto de relatoria do Ministro Celso de Mello, o julgador destacou que o Tribunal de Contas da União, no exercício das suas competências constitucionais previstas no artigo 71 da Carta Magna ${ }^{188}$, pode valer-se dos poderes implícitos para alcançar a máxima efetividade no cumprimento de suas atribuições.

Os poderes implícitos dos órgãos administrativos decorrem da hermenêutica constitucional realizada em atenção ao princípio da máxima efetividade. Por esse princípio,

\footnotetext{
${ }^{187}$ Art. $7^{\circ}$ Quem, convocado dentro do prazo de validade da sua proposta, não celebrar o contrato, deixar de entregar ou apresentar documentação falsa exigida para o certame, ensejar o retardamento da execução de seu objeto, não mantiver a proposta, falhar ou fraudar na execução do contrato, comportar-se de modo inidôneo ou cometer fraude fiscal, ficará impedido de licitar e contratar com a União, Estados, Distrito Federal ou Municípios e, será descredenciado no Sicaf, ou nos sistemas de cadastramento de fornecedores a que se refere o inciso XIV do art. 4o desta Lei, pelo prazo de até 5 (cinco) anos, sem prejuízo das multas previstas em edital e no contrato e das demais cominações legais.

${ }^{188}$ Art. 71. O controle externo, a cargo do Congresso Nacional, será exercido com o auxílio do Tribunal de Contas da União, ao qual compete: (...)

Revista de Direito da Administração Pública, ISSN 2595-5667, a. 2, v. 1, n. 3, julho-dezembro, 2017, p. 102
} 
entende-se que o hermeneuta pode interpretar a norma, a fim de extrair ao máximo a sua finalidade social para alcançar sua efetividade.

Para Luís Roberto Barroso, o referido princípio trata a efetividade da norma constitucional como um quarto plano da norma - ao lado da existência, da validade e da eficácia -, significando:

[...] a realização do Direito, a atuação prática da norma, fazendo prevalecer no mundo dos fatos os valores e interesses por ela tutelados. Simboliza a efetividade, portanto, a aproximação, tão íntima quanto possível, entre o dever ser normativo e o ser da realidade social (BARROSO, 1996, p. 375).

Nesta senda, a aplicação da teoria da desconsideração da personalidade jurídica em sede administrativa se justifica, na medida em que se confere um exercício mais efetivo da Corte de Contas no que toca à fiscalização e à responsabilização de infratores no bojo dos certames licitatórios. A desconsideração administrativa, então, decorre dos poderes implícitos, a fim de tutelar-se a indisponibilidade do interesse público e a moralidade administrativa.

Nesse contexto, destacou o Ministro relator, na ocasião do julgamento da tutela de urgência cautelar (MS n $\left.{ }^{\circ} 32.494-M C / D F\right)^{189}$ :

Tenho para mim, em juízo de mera delibação (em afirmação compatível, portanto, com esta fase de incompleta cognição), que o E. Tribunal de Contas da União, ao exercer o controle de legalidade sobre os procedimentos licitatórios sujeitos à sua jurisdição, possuiria atribuição para estender a outra pessoa ou entidade envolvida em prática comprovadamente fraudulenta ou cometida em colusão com terceiros a sanção administrativa que impôs, em momento anterior, a outro licitante (ou contratante), desde que reconheça, em cada situação que se apresente, a ocorrência dos pressupostos necessários à aplicação da teoria da desconsideração da personalidade jurídica, pois essa prerrogativa também comporia a esfera de atribuições institucionais daquela E. Corte de Contas, que se acha instrumentalmente vocacionada a tornar efetivo o exercício das múltiplas e relevantes competências que lhe foram diretamente outorgadas pelo próprio texto da Constituição da República. Isso significa que a atribuição de poderes explícitos ao Tribunal de Contas, como enunciados no art. 71 da Lei Fundamental da República, supõe que se lhe reconheça, ainda que por implicitude, a titularidade de meios destinados a viabilizar a adoção de medidas vocacionadas a conferir real efetividade às suas deliberações finais, permitindo, assim, que se neutralizem situações de lesividade, atual ou iminente, ao erário e ao ordenamento positivo.

$[\ldots]$

É por isso que, em juízo de sumária cognição, parece-me revestir-se de legitimidade constitucional a possibilidade teórica de aplicação da "disregard doctrine", que permitiria ao Tribunal de Contas da União adotar as medidas necessárias ao fiel cumprimento de suas funções institucionais e ao pleno exercício das competências que lhe foram outorgadas, diretamente, pela própria Constituição da República.[...] (BRASIL, 2013).

189 BRASIL. Supremo Tribunal Federal. MS no 32494 - MC/DF, Relator Min. Celso de Mello, julgado em $11 / 11 / 2013$ 
Ponderou o Ministro, ainda, que a aplicação da teoria da desconsideração da personalidade jurídica pelo TCU, na esfera administrativa, prescinde de permissivo legal expresso, em entendimento semelhante àquele externado pelo STJ no ROMS no 15.166. O Ministro ressaltou em seu voto que a própria teoria da disregard doctrine ingressou no ordenamento jurídico brasileiro pela via jurisprudencial e que já vinha sendo aplicada pelos tribunais brasileiros mesmo antes da sua positivação expressa nos diplomas legais.

Nas palavras do Ministro:

\begin{abstract}
De outro lado, e a despeito de o instituto da desconsideração da personalidade jurídica somente haver sido objeto de regulação legislativa em tempos mais recentes, como se verifica do Código Civil (art. 50) e dos diversos microssistemas legais, como aqueles resultantes do Código de Defesa do Consumidor (art. 28), da Lei $\mathrm{n}^{\circ}$ 9.615/98 ("Lei Pelé", art. 27), da Lei Ambiental (Lei no 9.605/98, art. 4) e da Lei n $^{\circ}$ $12.529 / 2011$ (art. 34), entre outros instrumentos normativos, parece-me que a ausência de autorização legal outorgando ao Tribunal de Contas da União competência expressa para promover "the lifting of the corporate veil" não violaria, aparentemente, o postulado da legalidade, eis que a aplicação, em nosso sistema jurídico, da "disregard doctrine", como sabemos, precedeu, em muitos anos, a própria edição dos diplomas legislativos anteriormente referidos, como resulta de decisões proferidas por nossos Tribunais judiciários (RT 511/199 - RT 560/109 RT 568/108 - RT 654/182-183 - RT 657/86 - RT 657/120 - RT 660/181 - RT 673/160) e reconhece o magistério da doutrina (RUBENS REQUIÃO, "Abuso de Direito e Fraude Através da Personalidade Jurídica", RT 410/1-12; ROGÉRIO LAURIA TUCCI, "Direito Processual Civil e Direito Privado - Ensaios e Pareceres", p. 162/164, item n. 5, 1989, Saraiva, v.g.).[...]

É importante acentuar que a aplicação do instituto da desconsideração ("disregard doctrine"), por parte do Tribunal de Contas da União, encontraria suporte legitimador não só na teoria dos poderes implícitos, mas, também, no princípio constitucional da moralidade administrativa, que representa um dos vetores que devem conformar e orientar a atividade da Administração Pública (CF, art. 37, "caput"), em ordem a inibir o emprego da fraude e a neutralizar a prática do abuso de direito, que se revelam comportamentos incompatíveis com a essência ética do Direito [...]. (BRASIL, 2013).
\end{abstract}

Contudo, mesmo tendo esposado o entendimento de que a aplicação da teoria da desconsideração da personalidade jurídica na esfera administrativa guarda compatibilidade com a ordem constitucional, o julgador deferiu a medida cautelar proposta pelo impetrante, a fim de suspender o acórdão proferido pela Corte de Contas.

Tal postura, firmada em sede de cognição sumária, se deu em razão da ausência de pronunciamento da Suprema Corte na matéria em questão e pela existência de eminentes juristas que se apoiam na cláusula de reserva de jurisdição como elemento imprescindível para a aplicação da teoria da desconsideração da personalidade jurídica.

Assim, finalizou o Ministro:

Todas as considerações que venho de fazer, ainda que expostas em sede de sumária cognição e fundadas em juízo meramente precário (sem qualquer manifestação Revista de Direito da Administração Pública, ISSN 2595-5667, a. 2, v. 1, n. 3, julho-dezembro, 2017, p. 104 
conclusiva, portanto, em torno da postulação mandamental), levar-me-iam a denegar o pleito cautelar ora deduzido na presente causa. Ocorre, no entanto, que razões de prudência e o reconhecimento da plausibilidade jurídica da pretensão deduzida pela parte impetrante impõem que se outorgue, na espécie, a pretendida tutela cautelar, seja porque esta Suprema Corte ainda não se pronunciou sobre a validade da aplicação da "disregard doctrine" no âmbito dos procedimentos administrativos, seja porque há eminentes doutrinadores, apoiados na cláusula constitucional da reserva de jurisdição, que entendem imprescindível a existência de ato jurisdicional para legitimar a desconsideração da personalidade jurídica (o que tornaria inadmissível a utilização dessa técnica por órgãos e Tribunais administrativos), seja porque se mostra relevante examinar o tema da desconsideração expansiva da personalidade civil em face do princípio da intranscendência das sanções administrativas e das medidas restritivas de direitos, seja, ainda, porque assume significativa importância o debate em torno da possibilidade de utilização da "disregard doctrine", pela própria Administração Pública, agindo "pro domo sua", examinada essa específica questão na perspectiva do princípio da legalidade (BRASIL. 2013).

\section{CONCLUSÃO}

A Lei n ${ }^{o}$ 12.846/2013 trouxe inegáveis avanços ao ambiente institucional de repressão à corrupção ao positivar a responsabilidade objetiva das empresas pelos atos lesivos praticados contra a Administração Pública nacional ou estrangeira.

A positivação da responsabilidade objetiva das pessoas jurídicas, nas searas civil e administrativa, atendeu às exigências dos compromissos internacionais firmados pelo Brasil e, sem dúvidas, representa o principal mecanismo legal da Lei Anticorrupção, apto a coibir os atos fraudulentos praticados pelas pessoas jurídicas em detrimento do Poder Público.

O escopo fundamental da Lei $n^{\circ} 12.846 / 2013$ demonstra que a principal preocupação da Lei Anticorrupção empresarial é fortalecer um ambiente ético institucional de combate à corrupção. A instituição de programas de ética e compliance, aliada à ameaça crível de que uma empresa possa ser responsabilizada objetivamente pelas pesadas sanções previstas na Lei, atuam como uma possível forma de prevenção à ocorrência de escândalos de corrupção.

Dentre os mais diversos mecanismos positivados na Lei ${ }^{\circ} 12.846 / 2013$, destacouse aquele que prevê a possibilidade de a Administração Pública aplicar a teoria da desconsideração da personalidade jurídica, a fim de estender as sanções contidas na Lei de regência às pessoas físicas dos sócios-administradores e com poderes de administração.

Da análise dos diversos posicionamentos doutrinários sobre a temática, concluiuse que a aplicação da disregard doctrine, no âmbito do processo administrativo de responsabilização, é medida que guarda plena compatibilidade com a ordem constitucional e com o ordenamento jurídico brasileiro, desde que verificados os pressupostos para a sua 
concreção: o desvio de finalidade da pessoa jurídica utilizada como instrumento de fraude, abuso de direito ou para provocar a confusão patrimonial.

A responsabilização dos sócios-administradores, por meio da desconsideração da personalidade jurídica, é válida na medida em que a Administração Pública pode dispor de seu regime jurídico administrativo para dar cumprimento a sua missão constitucional de guarda do princípio da moralidade administrativa e da indisponibilidade do interesse público.

Não se mostra possível invocar a cláusula de reserva de jurisdição como obstáculo intransponível para impedir que a Administração Pública, no cumprimento de suas atribuições constitucionais, seja impedida de levantar o véu da personalidade jurídica para, efetivamente, punir as pessoas físicas que se utilizaram fraudulentamente da pessoa jurídica para perpetrarem fraudes contra o Poder Público. As regras que norteiam a atuação da Administração Pública são regidas por normas de Direito Público, o que afasta a exigência de um ato jurisdicional para legitimar a disregard doctrine, tal como acontece no Direito Privado.

Portanto, é certo que a questão levantada neste estudo, quanto à constitucionalidade da aplicação da teoria da desconsideração da personalidade jurídica pela própria Administração Pública, ainda deve ser levada à apreciação do Poder Judiciário, que terá a tarefa de amenizar as imprecisões do legislador e conter os possíveis exageros que podem ser cometidos na exegese do artigo 14 da Lei $\mathrm{n}^{\circ} 12.846 / 2013$. A nova perspectiva traçada com o advento da Lei, no que toca ao combate à corrupção, deve ser interpretada em consonância com a ordem constitucional brasileira, para que sejam preservados os direitos dos administrados, salvaguardado o interesse público e contidos os excessos da Administração Pública.

\section{REFERÊNCIAS}

BARROSO, Luís Roberto. Interpretação e aplicação da Constituição. Fundamentos de uma dogmática transformadora. São Paulo: Saraiva, 1996

BRASIL. Superior Tribunal de Justiça. ROMS nº 15.166/BA, Rel. Min. Castro Meira, julgado em 07/08/2003. 
Superior Tribunal de Justiça. Resp 279273/SP, Rel. Ministro Ari Pargendler, Rel p/ Acórdão Ministra Nancy Andrighi, $3^{\text {a }}$ T., julgado em 4/12/2003.

. Superior Tribunal de Justiça. Resp 970.635/SP, Rel. Ministra Nancy Andrighi, Terceira Turma, julgado em 10/11/2009.

Supremo Tribunal Federal. MS nº 32494 - MC/DF, Relator Min. Celso de Mello, julgado em 11/11/2013.

Supremo Tribunal Federal. RHC 116204, Relatora: Min, Cármen Lúcia, Segunda Turma, julgado em 16/04/2013.

CARVAlHOSA, Modesto. Considerações sobre a Lei Anticorrupção das Pessoas Jurídicas: Lei no 12.846/13. $1^{\text {a }}$ ed. São Paulo: Revista dos Tribunais, 2015.

COELHO, Fábio Ulhôa. Curso de Direito Comercial: Sociedades. $18^{\mathrm{a}}$ ed. São Paulo: Saraiva, 2014, v. 2.

DI PIETRO, Maria Sylvia. Direito Administrativo. $27^{\mathrm{a}}$ ed., São Paulo: Atlas, 2015.

DINIZ, Eduardo Saad; SILVEIRA, Renato de Mello Jorge. Compliance, Direito Penal e Lei Anticorrupção. $1^{a}$ ed. São Paulo: Saraiva, 2015.

DIPP, Gilson; DE CASTILHO, Manoel L. Volkmer. Comentários sobre a Lei Anticorrupção. São Paulo: Saraiva, 2016.

FARIAS, Luciano Chaves de. Aplicação da teoria da desconsideração da personalidade jurídica na esfera administrativa. Fórum Administrativo: Direito Público, Belo Horizonte, n. 80, págs. 40-49, out. 2007.

GAGlianO, Pablo Stolze; PAMPLONA FILHO, Rodolfo. Novo Curso de Direito Civil: Parte Geral. 15 ed., São Paulo: Saraiva, 2013, v. 1. 
GASPARINI, Diógenes. Desconsideração Administrativa da Pessoa Jurídica. Revista RJML de Licitações e Contratos, Pinhais, $2^{\text {a }}$ ed., mar. 2007.

GRECO FILHO, Vicente; RASSI, João Daniel. O Combate à Corrupção e comentários à Lei de Responsabilidade de Pessoas Jurídicas. São Paulo: Saraiva, 2015.

JUSTEN FILHO, Marçal. Desconsideração da Personalidade Societária e Responsabilização de Terceiros na Lei de Improbidade Administrativa e na Lei Anticorrupção. Revista do Superior Tribunal de Justiça, Brasília, v. 241, n. 28, jan./fev/mar. 2016.

Comentários à Lei de Licitações e Contratos Administrativos.

$16^{\mathrm{a}}$ ed., São Paulo: RT, 2014, p. 1.084

MAMEDE, Gladston. Direito Empresarial Brasileiro: direito societário: sociedades simples e empresárias. $6^{\text {a }}$ ed. São Paulo: Atlas, 2012, v. 2.

MEIRELLES, Hely Lopes. Direito Administrativo Brasileiro, $28^{\mathrm{a}}$ ed., São Paulo: Malheiros, 2003.

MELlo, Celso Antônio Bandeira de. Curso de Direito Administrativo. São Paulo: Malheiros, 2004.

MOREIRA, Egon Bockmann; BAGATIN, Andreia Cristina. Lei Anticorrupção e quatro de seus principais temas: Responsabilidade Objetiva, desconsideração societária, acordos de leniência e regulamentos administrativos. Revista de Direito Público da Economia, Belo Horizonte, n. 47, p. 55-84, set. 2014.

PIRES, Antônio Cecílio Moreira. A Desconsideração da Personalidade Jurídica nas Contratações Públicas. São Paulo: Atlas, 2014.

REQUIÃO, Rubens. Abuso de direito e fraude através da personalidade jurídica. In: Aspectos modernos de direito comercial: estudos e pareceres. $2^{a}$ ed. São Paulo: Saraiva, 1988, v.1. 
Curso de Direito Comercial. $27^{\mathrm{a}}$ ed. rev. e atual. por Rubens Edmundo Requião. São Paulo: Saraiva, 2007, v. 1.

SARCEDO, Leandro. Compliance e responsabilidade penal da pessoa jurídica: construção de um novo modelo de imputação baseado na culpabilidade corporativa. São Paulo: LiberArs, 2016.

TAMASUSKAS, Igor Sant'Anna; BOTTINI, Pierpaolo Cruz. A interpretação constitucional possível da responsabilidade objetiva na Lei Anticorrupção. Revista dos Tribunais, São Paulo, v. 103, n. 947, set. 2014.

TOMAZETTE, Marlon. Curso de Direito Empresarial: Teoria Geral e Direito Societário. $6^{\mathrm{a}}$ ed., São Paulo: Atlas, 2013, v.1.

VAZ, Luciano Ferreira; MOROSINI, Fábio Costa. A implementação da Lei Internacional Anticorrupção no Comércio: $\mathrm{O}$ controle legal da corrupção direcionado às empresas transnacionais. Revista Brasileira de Estratégia e Relações Internacionais, Porto Alegre, v. 2, n. 3, jan./jun. 2013, p. 257-277. 